\title{
O Monstro e os Anormais na Filmografia de José Mojica Marins
}

\author{
Giancarlo Couto \\ Mestre em Comunicação Social pela Pontifícia Universidade Católica do Rio Grande do Sul (PUCRS) \\ giancarlobcouto@gmail.com \\ https://orcid.org/0000-0001-9757-522X
}

\section{Carlos Gerbase}

\author{
Docente no Programa de Pós-Graduação em Comunicação Social da Pontifícia Universidade Católica do Rio \\ Grande do Sul (PUCRS) \\ cgerbase@pucrs.br \\ https://orcid.org/0000-0001-9215-5840
}

RESU Mo Este artigo examina o personagem Zé do Caixão, de José Mojica Marins, a partir da concepção de "monstro", articulando conceitos de Mary Douglas, Noël Carroll e Michel Foucault. Do mesmo modo, o texto investiga as diferentes estruturações de alguns personagens da filmografia do diretor, que se enquadram no conceito de "anormais", de Michel Foucault. Para isso, o artigo se baseia nos escritos destes autores e na análise fílmica de algumas obras de José Mojica Marins, averiguando as reconfigurações desses personagens em diferentes momentos. Nossas conclusões versam sobre a relação dos filmes com seus contextos sociais, inseridos em diferentes épocas, demarcando a importância de se analisar o monstro e os anormais a partir das visões teóricas utilizadas.

PalavraS-Chave José Mojica Marins; Zé do Caixão; Monstro; Anormais

\section{Introdução}

O monstro é, talvez, o signo mais conhecido e comum nas narrativas clássicas de horror. Seja nos relatos da Idade Média, na literatura gótica ou até no cinema, esse ser muitas vezes é o centro das estórias. Do mesmo modo, se tornou muito comum falar do monstro humano, usando palavras como "monstruoso" a fim de adjetivar atitudes e pessoas em si. Nesse sentido, a monstruosidade e o monstro se confundem frequentemente, referindo-se a atos e seres reais ou fantasiosos, naturais ou sobrenaturais. Este artigo investigará algumas concepções acerca desses seres, partindo de dois conceitos que se articulam para conceber o monstro que ficou conhecido a partir da Idade Média e se desdobrou no anormal do século 
XX. Esses conceitos são os de "impureza" e "desordem", os quais, como mostraremos, muitas vezes se imbricam para dar origem à "anomalia" e ao "mal", sejam eles ontológicos ou sociais.

0 texto irá percorrer o trabalho de Mary Douglas (2014), a fim de entender as raízes antropológicas dos temas da impureza e anomalia. Posteriormente, basear-se-á na análise genealógica de Michel Foucault (2001; 2014; 2012) para estudar as concepções do grande monstro social do século XVIII, que se desdobrou na figura do anormal nascido no século XIX. A partir de categorias de Noël Carroll (1999), desenvolveremos a noção do monstro dentro do gênero de horror, a fim de introduzir então nossa análise da filmografia de José Mojica Marins, a qual se focará no seu mais célebre personagem, o Zé do Caixão. Nesse sentido, trabalharemos Zé do Caixão como a figura do monstro em paralelo com outros personagens das mesmas obras que representam os anormais, relacionando tais personagens com os aportes teóricos estabelecidos. Como ficará claro, essas figuras são aparições constantes na filmografia do diretor paulistano; todavia, são retratadas de distintas maneiras em diferentes longa-metragens e períodos. 0 objetivo então é retraçar a carreira do monstro Zé do Caixão e evidenciar as diferentes reconfigurações desses personagens satélites com o passar do tempo, nos seguintes filmes: $\grave{A}$ Meia-noite Levarei sua Alma (1964), Esta Noite Encarnarei no teu Cadáver (1967), o episódio "Ideologia" do filme O Estranho Mundo de Zé do Caixão (1968), O Ritual dos Sádicos (1969), Exorcismo Negro (1974), A Estranha Hospedaria dos Prazeres (1976), Delírios de um Anormal (1978) e Encarnação do Demônio (2008) ${ }^{1}$.

Antes de prosseguir, todavia, cabe ressaltar também que nosso foco se dá a partir dos estudos de Michel Foucault justamente por priorizar o que ele definirá como noção "jurídico-biológica" do monstro. Sendo assim, nossa escolha se dá por Douglas (2014) a fim de entender as bases antropológicas e biológicas do monstro, priorizando as questões anatômicas, enquanto que a visão de Foucault irá complementar tal proposta a partir de sua análise social. Reconhecemos aqui a importância dos mais diversos recortes epistemológicos acerca da figura do monstro, porém, além do pouco espaço que um artigo oferece para se retraçar todo

\footnotetext{
1 Todas as datas são referentes aos lançamentos dos filmes, menos O Ritual dos Sádicos, no qual decidimos destacar o ano de produção, visto que seu lançamento foi postergado até 1985, em razão de sua proibição pela Censura da Ditadura Civil-Militar brasileira (1964-1985).
} 
um estado da arte, acreditamos que os autores escolhidos são os que melhor dialogam com a nossa proposta de análise ${ }^{2}$.

\section{O Monstro social e a anomalia}

A questão da ordem e desordem é trabalhada diretamente por Douglas (2014) ao tratar sobre a pureza e impureza no universo antropológico. Ordem/desordem e pureza/impureza podem parecer, a princípio, conceitos distantes, porém, eles são vitais para se pensar a concepção do monstro e da anomalia. Basicamente, a desordem é situada como reduto da impureza. A ordem, por sua vez, só pode ser produzida na classificação de um sistema. Sua sistematização, consequentemente, produz inerentemente as anomalias, as sobras desse sistema que não se encaixam nas classificações. Uma anomalia confronta as linhas de percepção e geralmente é vista de modo negativo, como afetando o ordenamento de determinada cultura. Como exemplo de impureza, Douglas (2014) analisa as abominações do Levítico, as quais consistem em animais impuros que devem ser evitados na dieta. Estes animais são classificados de acordo com sua inserção em categorias.

Antes de mais, deve ser tido em conta que, no Antigo Testamento, o mal e o bem perpassam pela noção de benção divina. A benção é fonte das coisas boas e a falta de benção é fonte das ruins. "O trabalho de Deus através da benção é, essencialmente, criar a ordem pela qual os negócios dos homens prosperam. [...] Onde a benção é retirada e a força da maldição desencadeada, há esterilidade, peste, desordem." (Douglas 2014, 66). Logo, se Deus utiliza da benção para criar ordem, algo que está fora dessa ordem não foi abençoado e, consequentemente, se torna perigoso e/ou impuro.

Todas estas prescrições ${ }^{3}$ são prefaciadas por um mandamento geral: "Vós sereis santos, porque eu sou santo". Podemos concluir que a santidade é exemplificada pela integridade. A santidade requer que os indivíduos se conformem à classe à

\footnotetext{
${ }^{2}$ Para outras visões acerca do monstro, recomendamos sobretudo a leitura de Mikhail Bakhtin (1987), que traça uma genealogia da figura do monstro através do riso grotesco e de suas raízes populares. Ieda Tucherman (2012) oferece uma visão filosófica do assunto, priorizando uma análise dos freaks, cyborgs e outros modos de percepção do monstro na contemporaneidade. Jeffrey Cohen (2000) reúne visões ricas de diferentes autores e áreas do conhecimento acerca dessas figuras. No campo do cinema, a dissertação de Fuad Jaudy (2010) reconta a história do Monstro na sétima arte, trazendo análises de obras seminais da Universal.

${ }^{3}$ Aqui Douglas (2014) se refere a proibições ligadas à moral.
} 
qual pertencem. E a santidade requer que diferentes classes de coisas não se confundam.

Outro conjunto de preceitos aperfeiçoa esta ideia. A santidade significa manter distintas as categorias de criação. Ela, portanto, envolve definição correta, discriminação e ordem. Sob este título, todas as regras de moralidade sexual exemplificam o santo (Douglas 2014, 70).

A santidade, então, está ligada a unidade e integridade com o santo, tanto do homem quanto de seu povo. As regras dietéticas apontadas no Levítico são, então, a exemplificação dessa busca por uma santidade una, integrada e que segue esses princípios de classificação ordenada. Logo, essas regras dietéticas funcionam como signos para relembrar constantemente dessa necessidade de unidade com Deus.

Comecemos pelos animais permitidos na alimentação. 0 gado, o camelo, o carneiro e a cabra eram criados pelos israelitas. Após lidarem com eles, não era necessário lavar as mãos para se entrar no Templo. Estes bichos eram providos por Deus, habitavam a terra dada e abençoada pelo criador, logo eram puros. São animais que estão inseridos na ordem divina de providência. A partir disso se desenrolam duas características que são ligadas a eles, o seu ruminar e o casco fendido. É em torno das dissonâncias dessas características que alguns animais são proibidos. Acreditava-se que a lebre, por exemplo, com seu constante ranger de dentes, ruminava, porém seu consumo era proibido por ela não ter o casco fendido. 0 porco tem o casco fendido, porém não rumina, logo seu consumo é proibido. A pureza então é definida pela classificação de categorias e aqueles animais que não se adequam a elas são considerados impuros e não devem ser consumidos (Douglas 2014, 72).

No que concerne aos animais selvagens, os critérios de impureza seguem os de classificação e ordem:

Para atingir este esquema precisamos retornar ao Gênesis e à criação. Aqui se desdobra uma classificação tripartida, dividida entre terra, as águas e o firmamento. 0 Levítico toma este esquema e atribui para cada elemento o tipo de vida apropriado. No firmamento, aves de duas pernas voam com asas. Na água, peixes com escamas nadam com nadadeiras. Na terra, animais de quatro pernas pulam, saltam ou andam. Qualquer classe de criaturas que não esteja equipada para o tipo correto de locomoção no seu elemento é contrária à santidade. 0 contato com ela desqualifica uma pessoa a aproximar-se do Templo. Portanto, qualquer coisa da água que não tenha nadadeiras e escamas é impura (11, 10-12). Não é dito a respeito dos hábitos predatórios ou de alimentação de carniça. 0 
único teste seguro de limpeza para um peixe são suas escamas e a sua propulsão por meio de nadadeiras (Douglas 2014, 72).

A definição de impureza desses animais segue então suas categorizações, ou melhor, a falta de possibilidade de enquadramento desses animais em categorias pré-estabelecidas no Gênesis. Eles são anomalias de formas, restos fora de um padrão, impossíveis de se classificar. A impureza está no erro, na ambiguidade e, principalmente, no deslocamento. Enguias são exemplos de animais que vivem nas águas, mas não são peixes, por isso são impuros. Do mesmo modo, alguns répteis andam na terra, mas não são quadrúpedes, e insetos voam, mas não são aves.

Em termos sociais, o deslocamento do indivíduo funciona também como uma desordem marcada pelo impuro. Isso fica claro se percebermos a separação que se estabeleceu com a ascensão da burguesia destacada por Vigarello (1996) ${ }^{4}$. As classes sociais na Europa funcionavam como separação e classificação dos tipos e graus de limpeza dos cidadãos. Não por acaso, Georges Bataille (apud Santos 2013) estabeleceu seus estudos acerca do abjeto relacionando-o a partir da visão das classes altas em relação às baixas e aos excluídos. Do mesmo modo, Clark (2006) ressalta que as bruxas do século XVI e XVII eram relacionadas com a desordem, irracionalidade e tom carnavalesco ${ }^{5}$. Eram vistas como seres impuros e seus malefícios geralmente giravam em torno da sujeira, doença e infecciosidade (tanto física quanto da alma). Como Douglas (2014) conclui, o ambiente social é dividido por linhas e, quando essas percepções se confundem, a poluição aparece como um denominador a fim de marcar essas linhas divisórias. 0 perigo está no deslocamento e também na intrusão. "Joana D’arc pode ser tomada como um esplêndido protótipo dessas: uma camponesa na corte, uma mulher no exército, uma intrusa no conselho de guerra; a acusação de que era uma bruxa põe-na inteiramente nessa categoria" (Douglas 2014, 127).

Essas coordenadas estabelecidas para se pensar tanto o indivíduo quanto o animal, ambos deslocados tanto num nível ontológico quanto social, vão

\footnotetext{
${ }^{4}$ Vigarello (1996) destaca a pastoral da miséria, no século XIX, quando a busca por métodos de higienização toma contornos morais e sociais. As classes mais altas veem a necessidade de impor atos de limpeza às mais baixas, pois a sujeira se classifica como desleixo, como falta de virtude moral e é nela que todo tipo de vício se constitui e contagia. Do mesmo modo, se institui a regularidade do banho em prisões e hospícios.

${ }^{5} 0$ carnaval é claramente uma subversão momentânea da ordem.
} 
na mesma direção para se pensar o monstro, seja ele o humano/social que habita o cotidiano dos relatos bárbaros criminosos, seja o monstro artístico, da literatura e do cinema.

Em seu curso no Collège de France, leccionado entre 1974 e 1975, Michel Foucault estabelece algumas categorias para pensar o surgimento do conceito de "anormal" para a psicanálise. Para ele, essa noção que temos hoje sobre os sujeitos desviantes da sociedade começa a se estabelecer no século XVIII, com um sujeito que ele aponta como "o monstro". Essa é a primeira das categorias apontadas por Foucault (2001) e a que interessa a esse artigo $^{6}$

\begin{abstract}
O contexto de referência do monstro humano é a lei, é claro. A noção de monstro é essencialmente uma noção jurídica - jurídica, claro, no sentido lato do termo, pois o que define o monstro é o fato de que ele constitui, em sua existência mesma e em sua forma, não apenas uma violação das leis da sociedade, mas uma violação das leis da natureza. Ele é, num registro duplo, infração às leis em sua existência mesma. O campo do aparecimento do monstro é, portanto, um domínio que podemos dizer "jurídico-biológico". Por outro lado, nesse espaço, o monstro aparece como um fenômeno ao mesmo tempo extremo e extremamente raro. Ele é o limite, o ponto de inflexão da lei e é, ao mesmo tempo, a exceção que só se encontra em casos extremos, precisamente. Digamos que o monstro é o que combina o impossível com o proibido (Foucault 2001, 69-70) 7 .
\end{abstract}

Tal concepção é muito próxima de Gil (2006), que coloca os monstros como alteridades que confirmam a norma, como o Mesmo do Outro que chama a atenção do homem para suas diferenças, ou seja, aquele diferente que aparece para confirmar ao homem sua normalidade. Traçando uma genealogia do monstro, Foucault (2001) retoma as diferenciações dadas na antiguidade romana. Já nessa época se distinguia claramente entre o defeituoso, num sentido médico, de doença, e o monstruoso, pelo viés jurídico. Na Idade Média, o termo se inclina para a concepção do misto. 0 monstruoso é aquele que é composto da mistura ${ }^{8}$, seja ela entre reinos (animal e humano, como o homem com cabeça de boi); mistura de espécies (porco com cabeça de carneiro); mistura de corpos (homem com

\footnotetext{
${ }^{6}$ As outras duas são o "indivíduo a corrigir" e o "jovem masturbador", que, apesar de sua importância no esquema foucaultiano, não nos interessam no momento.

7 Tal reflexão está presente também em Kant (Lemos, 2014).

${ }^{8}$ Ou seja, o deslocamento das categorizações.
} 
duas cabeças); ou mistura de sexos (hermafrodita). Todavia, o monstro não é apenas esse disforme da Idade Média, mas sim a afronta às leis, sejam elas divinas, naturais ou civis. "Só há monstruosidade onde a desordem da lei natural vem tocar, abalar, inquietar o direito, seja o direito civil, o direito canônico ou o direito religioso" (Foucault 2001, 79). É aí que a monstruosidade se distingue da enfermidade, pois é o resultado do abalo às leis naturais e a essas leis jurídicas apontadas. A enfermidade também abala a ordem natural, porém não é uma afronta à sociedade ou à religião.

É a partir do século XVIII, porém, que Foucault (2001) nota o estabelecimento das noções de monstruosidade que serviram de coordenada para a concepção do anormal moderno. 0 foco não é mais tanto a desordem natural, apesar disso ter seu quinhão de importância, mas sim como essa desordem natural se relaciona com uma desordem moral. Entra em cena a monstruosidade do comportamento. 0 misto se torna mais um deslize da natureza, porém, o monstruoso é aquele que transforma o deslize natural em errância moral. É a partir daí que a monstruosidade se torna criminosa, explodindo sob a forma jurídica. Antes, a monstruosidade era uma característica do criminoso, agora ela é uma categoria em si. Surge Sade, a figura do criminoso monstruoso, assim como também os monstros morais da literatura gótica. Daí se desenrola outra questão: já que o monstro está à parte das leis, deve ele ser julgado por elas? Não deve o monstro ser simplesmente excluído, como nas comunidades primitivas? Esse princípio de negação do contrato social por parte do monstro acaba por criar um refúgio para ideais igualmente repelidores por parte da sociedade contra as anomalias sociais.

No âmbito político, a monstruosidade age como caracterização dos inimigos em momentos de reorganização do poder político. No caso da França, Maria Antonieta é mostrada em panfletos jacobinos como uma monstra que suga o sangue dos seus súditos. Ela é também atacada do ponto de vista moral, acusada de ter relações incestuosas e homossexuais. Do mesmo modo, a monarquia se refere aos revolucionários como monstros canibais. Se espalham os relatos de revolucionários que estupram e assam para comer membros da nobreza. Os ataques através dos discursos se articulam justamente nessas noções do monstro antropofágico, que come seus semelhantes e suga seu sangue - não apenas como metáforas, mas também literalmente (Foucault 2001).

Em todo esse processo revolucionário, com essas novas mecânicas de poder e punição, surge também uma literatura de horror preocupada com 
as mesmas questões. 0 tirano e o homem do povo sanguinolento se materializam sob duas formas:

De um lado, temos o monstro por abuso de poder: é o príncipe, é o senhor, é o mau padre, é o monge culpado. Depois, temos também, nessa mesma literatura de terror, o monstro de baixo, o monstro que volta à natureza selvagem, o bandido, o homem das florestas, o bruto com seu instante ilimitado (Foucault 2001, 124-125).

Paralela à concepção do monstro surge outra categoria, os incorrigíveis. Se trata dos indisciplinados, que não conseguem se adaptar às leis e organizações. Os incorrigíveis são flagrados em escolas, internatos, no exército etc. Se evidenciam os loucos, os obcecados, os deficientes, todos eles à margem das técnicas de disciplinamento (Foucault 2001). A disciplina aqui é o ponto de inflexão da ordem através de instituições socioeducativas e aqueles que a elas não se adaptam se tornam as sobras do sistema (Portocarrero 2004). Como restos de categorização, os desajustados ocupam um não-lugar numa classificação social, sendo anomalias de um sistema regido por um processo de normalização dos indivíduos. É da mistura entre o monstro do século XVIII e esses incorrigíveis que precisam ser internados que surge o anormal do século XIX, ser que parece permanecer até o século XX (Foucault 2001).

\section{0 monstro no horror artístico}

Carroll (1999) fornece úteis ferramentas de categorização para se conceituar o que ele chama de horror artístico9. Primeiramente, é interessante notar que a classificação do gênero horror na arte se nomeia justamente pelo afeto que ele causa. Ou seja, temos aqui, prontamente, uma nomenclatura que surge a partir da relação do espectador com a arte. Poder-se-ia apontar que monstros também funcionam como um dispositivo para se classificar o gênero, todavia, como o autor frisa, monstros aparecem em outros tipos de narrativas. 0 que os coloca como elementos do horror são a relação deles com os personagens. Os monstros causam repugnância. E é isso que queremos destacar, justamente por se

\footnotetext{
${ }^{9} \mathrm{O}$ autor difere aqui o "horror artístico" do horror num modo geral, que ele chama de natural e correlaciona com o cotidiano. 0 horror artístico, nesse sentido, se refere estritamente ao gênero e aos afetos despertados em obras artísticas.
} 
aproximar da definição de impuro trazida por Douglas (2014). Carroll (1999, 31) ressalta: "Nas obras de horror, os humanos encaram os monstros que encontram como anormais, como perturbação da ordem natural". Diferente do fantástico, onde monstros podem causar medo e representar perigo, eles não são descritos ou demonstrados como anomalias da ordem, pois fazem parte daquele universo. No horror, todavia, os monstros causam a repugnância, são confusões impuras, quebras da ordem. É por isso que as reações dos personagens em relação aos monstros nas histórias de horror não são apenas de medo, mas também de nojo, "a ameaça mistura-se à repugnância, à náusea e à repulsa" (Carroll 1999, 39). Não por acaso que, como aponta o autor, as histórias de horror comumente relacionam os monstros à imundície, deterioração, deformidade etc.

No contexto da narrativa de horror, os monstros são identificados como impuros e imundos. São coisas pútridas ou em desintegração, ou vêm de lugares lamacentos, ou são feitos de carne morta ou podre, ou de resíduo químico, ou estão associados com animais nocivos, doenças ou coisas rastejantes. Não só são muito perigosos como também provocam arrepios. Os personagens vêem não só com medo, mas também com nojo, com um misto de terror e repulsa (Carroll 1999, 39).

Carroll (1999) conclui então que a constituição do monstro se dá por esses dois fatores, os monstros precisam ser ameaçadores e impuros. Aqui, nota-se claramente a junção na narrativa de categorias já estabelecidas por Douglas (2014) e Ricoeur (1982) ${ }^{10}$ na constituição do mal impuro. 0 campo artístico utiliza as mesmas categorias de sistematização antropológica da sociedade ${ }^{11}$. Daí ser tão recorrente em diversas narrativas as palavras "eles", "aquilo", "coisa" ao se referir a esses seres, sugerindo que não há como categorizá-los ${ }^{12}$. Como Schiller $(2011,43)$

\footnotetext{
${ }^{10}$ Ricoeur (1982) estabelece através da genealogia do conceito de "mancha" essa noção do mal impuro, que infecta o homem.

${ }^{11}$ Carroll (1999) se reporta diretamente ao estudo de Douglas (2014) para falar sobre os monstros.

12 Alguns exemplos: 0 filme "A Ameaça que Veio do Espaço" originalmente se chama "It Came from Outer Space". Na mesma linha, "O Mundo em Perigo" se chama originalmente "Them!". Do mesmo modo, o livro de Stephen King, chamado "It", não designa o que é o monstro, que inclusive se metamorfoseia e constantemente muda de categoria. Homenagem ao livro "The Shadow Over Innsmouth", de H.P. Lovecraft, a música "The Thing that Should Not Be" (A coisa que não deveria ser), da banda Metallica, retoma diretamente esses conceitos também, girando sua narrativa em torno do medo do híbrido, do rastejante, do que vem das profundezas do mar e vagueia por locais proibidos.
} 
destaca, o medo do indeterminado conduz a fantasia, "tudo o que é incomum é terrível".

Carroll (1999) também destaca como esses monstros, ao serem antinaturais e expressões dessas anomalias de categorização, são seres que desafiam o modo de pensar da sociedade. Além de fisicamente ameaçadores, eles são cognitivamente ameaçadores. Por isso, é comum em narrativas que eles causem a confusão mental e até levem os personagens à insanidade. À beira da Loucura (In the Mouth of Madness, 1994), de John Carpenter, e A Hora do Lobo (Vargtimmen, 1968), de Ingmar Bergman, são exemplos curiosamente próximos nesse sentido. No filme de Carpenter, quanto mais inserido no universo daquela cidade, no meio de monstros e alucinações, mais o protagonista perde a razão e acaba por enlouquecer diante de tal cenário caótico. 0 mesmo acontece na ilha do filme sueco, onde os protagonistas adentram no emaranhado de suas mentes, conduzidos por estranhas aparições. De modo ainda mais exagerado, a visão das criaturas de Bird Box (2018), de Susanne Bier, leva as pessoas diretamente ao suicídio. Tal proposição poderia ser vista como uma consequência extrema da incapacidade de compreensão da alteridade do Outro monstruoso proposta por Gil (2006).

Esse modo de percepção sistematizada nos leva, por sua vez, ao contexto moral das narrativas de horror em geral. Os monstros, além de serem anomalias físicas de um sistema, são anomalias sociais. 0 monstro, nas narrativas de ficção, é aquilo que afronta as categorias, visa subverter a ordem do mundo através do mal e precisa ser vencido pelos "mocinhos". Sendo assim, quando se destrói um monstro, está se repelindo a diferença, excluindo os resíduos da sociedade e restabelecendo a ordem. Ora, essa narrativa é moral por si só. Carroll (1999) indiretamente notou que, nas narrativas de horror, são trabalhadas questões já levantadas por Foucault (2001) no que concerne aos anormais. 0 autor estadunidense, por sua vez, destaca como, além de serem transgressões por si só, os monstros das ficções cometem transgressões. Numa estrutura narrativa básica em três atos, nota-se um grande padrão que começa na normalidade, até que surge algum mal que funciona como quebra dessa normalidade e que, por fim, no terceiro ato, é confrontado e superado, para o restabelecimento da ordem original.

Aplicada ao gênero do horror, a interpretação análoga poderia funcionar da seguinte forma: com a irrupção do monstro numa ficção de horror, é aberto um espaço cultural em que os valores e os conceitos da cultura podem ser invertidos, 
revertidos e postos de dentro para fora. [...] Mas a condição que permite essa transgressão da norma é que, quando tudo foi dito e feito, e a narrativa chega a seu fim, a norma seja reconstituída - o monstro ontologicamente ofensivo seja eliminado e seus horríveis feitos, punidos. Assim, a norma fica mais forte do que antes; ela foi, por assim dizer, testada; sua superioridade sobre o anormal foi justificada; e pensamentos e desejos supostamente caprichosos, talvez sorumbáticos - da perspectiva do ponto de vista cultural dominante - , foram, figuradamente falando, lancetados (Carroll 1999, 182).

Essa estrutura básica e comumente difundida retoma todos os passos do ordenamento da metafísica cristã. Aqui, há o fechamento desse ciclo entre puro e impuro, ordem e desordem. 0 gênero de horror serve como uma exemplificação artística sobre como esses conceitos se engendram, costurando-os e desenvolvendo-os na narrativa. Desta feita, o mal está geralmente relacionado com algum tipo de desordem impura que deve ser combatida para se estabelecer novamente a ordem.

\section{Zé do Caixão - Monstro e anormal}

De certa forma, a carreira de José Mojica Marins é marcada pela anormalidade. Em diversos momentos de sua vida o cineasta paulistano foi tachado como "estranho", "louco", "anormal", dentre outros adjetivos. No geral, pode-se dizer que Mojica recebeu bem essas alcunhas e soube usá-las a seu favor. Desenvolvendo uma carreira no cinema focada no grotesco e no horror, o cineasta da Boca do Lixo paulistana ${ }^{13}$ se firmou no cenário nacional e internacional com seus filmes de horror fantástico e seu personagem, o Zé do Caixão.

A relação da obra de José Mojica Marins com a teoria de autores europeus e estadunidenses pode soar deslocada para alguns, mas como apontado por Melo (2010), as principais influências do diretor vêm das histórias em quadrinhos estrangeiras, bem como dos filmes da produtora estadunidense Universal e da britânica Hammer ${ }^{14}$. Mojica incorpora em suas obras o estilo gótico desses filmes, bem como personagens

\footnotetext{
13 Bairro de São Paulo onde ficava a produtora de Mojica. O local é famoso pelo movimento de cinema independente e de baixo custo.

${ }^{14}$ A Universal produziu diversos filmes de horror com personagens clássicos da literatura gótica (Drácula, Frankenstein, a Múmia, o Lobisomem etc) nas décadas de 1930 e 1940. A Hammer produziu novas versões destes clássicos nas décadas de 1950 e 1960.
} 
semelhantes. Note-se a influência de Drácula na capa, cartola e andar altivo de Zé do Caixão. Por seu turno, o personagem de Bruno, o anormal de Esta Noite Encarnarei no teu Cadáver, é claramente inspirado no ajudante do Dr. Frankenstein. Sendo assim, mesmo se utilizando os medos e religiões tipicamente nacionais, são inegáveis as influências pop e estrangeiras do diretor, fundamentais para os eixos de análise que estabelecemos aqui. 0 monstro de Mojica se constitui através de preceitos narrativos básicos da literatura e do cinema de horror. Fã do gênero, Mojica o consumiu desde criança, seja no cinema que seu pai tinha na Vila Anastácio, seja lendo as revistas em quadrinhos pelas quais era aficionado (Barcinski e Finotti 2015).

A estreia de Mojica no gênero do horror se deu em 1964, com À Meia-Noite Levarei sua Alma, filme que conta a história de Zé do Caixão, um coveiro que vive numa pequena cidade do interior. Obcecado por gerar um filho perfeito, que será a continuidade de seu sangue, Zé faz de tudo para conquistar tal objetivo, inclusive assassina sua esposa infértil e estupra a cônjuge de seu melhor amigo, acreditando que ela é a mulher ideal para gerar seu filho. 0 filme é cheio de momentos violentos e tem fortes aspectos religiosos, principalmente no confronto entre Zé do Caixão, um niilista que zomba de todas as religiões e crenças locais, e os demais cidadãos da cidade, que lhe colocam a pecha de amaldiçoado e demônio.

A essa altura, não pode haver dúvida de que À Meia-Noite Levarei sua Alma é um filme radical, tanto na forma como no conteúdo. E nada é mais radical no filme do que sua blasfêmia. À Meia-Noite é carregado de uma virulência anticristã extremada até para os padrões atuais. Zé do Caixão zomba de padres, ri da procissão santa e chama cristãos de "idiotas". Quando vê um crucifixo na parede, diz que aquilo não passa de um "símbolo da ignorância". Não é difícil de imaginar o choque que deve ter sido para o público suburbano paulista ouvir um personagem vomitando injúrias como essas (Barcinski e Finotti 2015, 177).

O sucesso e polêmica em relação ao filme se deve diretamente a esses aspectos. Muitas pessoas se horrorizaram com a película e boatos se espalharam pela cidade, acusando Mojica de ter pacto com satanás. Mesmo que no final do filme Zé do Caixão se arrependa e seja punido com a morte pelos espíritos das pessoas a quem ele fez mal, o choque de todas as falas antirreligiosas causou espanto nos espectadores, principalmente aqueles mais apegados às suas crenças. A partir daí, Mojica focou em seus filmes de horror, sempre protagonizados ou contando com participações célebre de seu personagem Zé do Caixão. 
A primeira aparição de Zé do Caixão, em À Meia-Noite Levarei Sua Alma, já denota uma quebra que demarca seu deslocamento social diante dos outros personagens. Num funeral, onde uma viúva chora e os demais tentam consolá-la, o protagonista monstruoso surge entre os demais a partir de um corte seco. Todo vestido de preto e com sua cartola e capa, Zé se destaca por sua excentricidade ao se vestir, em meio aos moradores de uma cidade do interior. Nesse plano já fica claro que ele é um forasteiro ${ }^{15}$ que não pertence àquele lugar, não se veste como os moradores dali e caminha de modo diferente, sempre altivo e a dar ordens para os demais, estes sempre de cabeça baixa e submissos. Zé encarna o monarca vampiresco. Ele parece sugar a energia dos demais, os considera inferiores, os destrata e os violenta física e mentalmente.

A cena seguinte retoma o sentido de Zé do Caixão como o monstro antropofágico. Após chegar em casa do enterro, ele profere: "esse enterro me deu uma fome" e pede que a esposa lhe prepare o jantar. Ao saber que não terá carne, pois é sexta-feira santa, ele tem um ataque de cólera e reclama, "hoje eu como carne, nem que seja carne de gente!" e sai para comprar carne de carneiro. Em seguida, come o assado com as mãos em frente à janela, enquanto zomba da romaria que passa em frente à sua casa. Em primeiro lugar, há a constante relação da carne que Zé quer comer com a antropofagia. Ele relaciona sua fome com a tristeza dos demais, fala de comer carne de gente; em outra cena, após decepar o dedo de um homem com uma garrafa quebrada, diz "Depois de uma cena dessas a gente chega a ficar com fome". Além dessas menções indiretas ao antropofagismo, o gesto de comer carne numa sexta-feira santa é um ato contra a lei religiosa daquele ambiente. Zé usa isso para afrontar os costumes e as pessoas que acreditam no pecado de tal conduta. Além disso, ainda obriga um homem a comer carne. Desse modo, Zé age afrontando as leis daquela sociedade, não apenas através de seus atos nefastos (posteriormente ele cometerá crimes de fato, como o estupro e assassinato), mas sim através de sua zombaria e modo subversivo de agir. Não à toa, causa medo e repulsa antes mesmo de cometer qualquer crime. Ele é o monstro que nega constantemente o contrato social da comunidade. ${ }^{15}$ Essa é uma característica em comum com Maria Antonieta, que era estrangeira. Segundo Foucault (2001),
esse era um ponto que contava nesse sentido de não pertencimento à comunidade que ela comandava. 
Três anos depois, Mojica lançou Esta Noite Encarnarei no Teu Cadáver, continuação da saga de Zé do Caixão, em busca da mulher perfeita para gerar seu filho. Após ser julgado pelos assassinatos e solto por falta de provas, o personagem volta ao vilarejo, onde todos ainda o temem. Em seu retorno, o medo é ainda maior do que antes. Ao verem-no se aproximar, os moradores, até então felizes transitando pela rua, fogem para suas casas. Zé continua desprezando-os, porém, dessa vez ele não representa mais o monarca antropofágico, mas sim o homem sádico e violento que subverte a ordem a partir de baixo. Após sua ausência, a cidade tem outro dono, um coronel que coordena o local, amparado por seus capangas. Esse coronel detém o poder na cidade e pretende excluí-lo dali. A população quer o mesmo e, quando mulheres somem, rapidamente condenam Zé sem provas. Mesmo sendo ele de fato o culpado, é interessante perceber que todas as acusações giram em torno de seu modo de agir, suas roupas e seu ceticismo em relação às crenças religiosas. Zé é visto como a anomalia que representa o perigo. Como Foucault (2001) destaca, não se julga o ato, mas sim a constituição social do indivíduo. Do mesmo modo, Zé continua afrontando a lei, seja através de seus crimes, seja com palavras contra ela. $\mathrm{Na}$ cena em que sonha ser arrastado para o inferno, o coveiro repete diversas vezes que não acredita na lei, desdenhando de sua iminente punição. Outro aspecto disso é que Zé sempre tem como principais inimigos os representantes do poder e das instituições, principalmente padres e policiais. É também em Esta Noite Encarnarei no Teu Cadáver que entram em cena as figuras que aparecerão constantemente nos filmes de Mojica, os anormais. Neste, o anormal é representado principalmente por Bruno, o ajudante corcunda de Zé do Caixão. 0 homem é disforme tanto no corpo quanto na mente: além da corcunda, tem deformações no rosto e demonstra problemas mentais e falta de julgamento moral. É a figura do louco que a partir do século XVII precisou ser trancafiado. Aqui ele é o ajudante do monstro, sendo manipulado por ele para fins maléficos.

O Estranho Mundo de Zé do Caixão marca o começo da parceria entre Mojica e o roteirista Rubens Luchetti, prolífico escritor de literatura pulp, envolvendo crimes e suspense. Além disso, Luchetti escrevia roteiros para histórias em quadrinhos e outros filmes de horror ${ }^{16}$. $O$ Estranho Mundo de Zé do Caixão é composto por três histórias sem ligação, funcionando como contos, porém a que nos interessa aqui é a última, chamada "Ideologia".

${ }^{16}$ Excetuando-se Encarnação do Demônio, Luchetti participou de todas as obras citadas a partir daqui. 
Nela abundam os anormais. A história começa num programa de televisão, mostrando o debate entre alguns especialistas, dentre eles o Professor Oãxiac Odéz ${ }^{17}$, que defende sua tese de que o instinto prevalece sobre a razão. Ao final do programa ele convida seu rival de debate para ir a sua casa e conhecer um pouco mais sobre suas teorias. 0 homem aceita e leva sua esposa. Ao chegar no local, porém, os dois são presos e obrigados a assistir a uma série de demonstrações violentas de tortura e sadismo. Oãxiac explica que seus experimentos consistem em submeter os seres humanos a situações extremas e assim provar que a razão é mais fraca que o instinto. Acompanhamos então a algumas dessas demonstrações, como um homem que é torturado e por fim comido vivo por outros que passavam fome; homens que assediam uma moça e, por fim, jogam ácido em seu rosto; e um casal que tem como fetiche se autoflagelar com líquidos ferventes. Oãxiac indica que fará experimentos com o homem e sua esposa e que se eles permanecerem racionais por sete dias terão a liberdade; caso contrário, a morte. 0 casal é preso em jaulas separadas, sem receber água nem comida. Quando Oãxiac ameaça matar a mulher, o marido oferece sua vida. Ao se virar para ele, a mulher intervém e diz que ela é quem deve morrer. Oãxiac diz que eles passaram pela primeira prova e que, por enquanto, o amor persiste. Nos outros dias eles não recebem nem água nem comida, até que no sexto, Oãxiac traz um banquete para o homem. 0 homem diz para dar a comida à mulher, mas Oãxiac ordena aos criados que dêm a comida aos cães. 0 homem então cede e começa a comer vorazmente o banquete enquanto a mulher observa. No último dia a mulher implora por água. Oãxiac a solta de sua jaula e lhe dá um copo vazio, lhe dizendo que não tem água, mas tem algo melhor para matar sua sede, o sangue do marido. Ela não faz menção de impedir que Oãxiac mate o esposo, para então beber o sangue que jorra de sua jugular.

Assim como em Esta Noite Encarnarei no Teu Cadáver, em O Estranho Mundo de Zé do Caixão os anormais são ajudantes de Zé do Caixão. São os sádicos, os desviantes sexuais, os amorais, aqueles que perderam a razão e se relegaram ao instinto. Oãxiac segue sendo um monstro sádico que demonstra suas teses através de diversos experimentos, afligindo as pobres almas de suas vítimas. Aqui novamente temos também a antropofagia, o vampirismo da mulher que mata a sede com o sangue do ${ }^{17} \mathrm{O}$ personagem é interpretado pelo próprio Mojica e tem esse nome (Zé do Caixão ao contrário) pois, nesse
momento, o diretor havia perdido os direitos sobre o personagem. 
marido. Zé não apenas é o mal, como também faz com que os inocentes causem o mal. Se em À Meia-Noite Levarei Sua Alma ele obriga um homem a comer carne de cordeiro na sexta-feira santa, aqui ele obriga uma mulher a beber o sangue do marido. 0 final do filme conduz ao canibalismo claro. Zé finalmente passa das menções indiretas ao ato, se consagrando como o monstro antropófago. Seus discípulos agem do mesmo modo e todos se alimentam dos membros do casal recém morto num banquete.

O Ritual dos Sádicos propõe uma discussão mais direta acerca daqueles vistos como anormais do século XX. Em 1969, após seguidos insucessos de financiamento por parte de produtoras, problemas com empresários e com a censura, Mojica se sentia fortemente incomodado e resolveu que iria descarregar isso em seu próximo filme, o qual ele ainda não tinha ideia sobre o que seria.

\begin{abstract}
A ideia para a fita surgiu por acaso: andando certa noite próximo a uma delegacia, Mojica viu uma prostituta grávida sendo surrada por policiais. A cena o aterrorizou. Na noite seguinte voltou ao local e, conversando com outras prostitutas, descobriu que a mulher havia sido morta. "Quem entra nessa delegacia não volta viva, não!", disse uma delas. Ele não conseguia tirar a imagem da cabeça. Nunca vira nada tão assustador. Resolveu esquecer o terror ficcional de monstros e vampiros e fazer um filme sobre o terror do dia a dia, da miséria e da violência urbana. (Barcinski; Finotti 2015, 380).
\end{abstract}

Além desse episódio, Mojica demonstrava curiosidade com todos os movimentos de contracultura da época. Os hippies, a Tropicália, o rock, o amor livre e o uso de drogas eram temas em voga e Mojica decidiu que iria misturar tudo isso em sua próxima história (Barcinski e Finotti 2015).

A trama de $O$ Ritual dos Sádicos gira em torno de uma mesa onde especialistas debatem diversos episódios relatados por um pesquisador da área da psicologia. Eles contam casos em que usuários de tóxicos, após ingerirem as substâncias, cometem perversões sexuais. Em estrutura episódica, o espectador presencia esses relatos comentados pelos participantes do debate. Depois de alguns episódios, o pesquisador conta sobre seus experimentos, nos quais utilizou viciados e os submeteu a uma série de situações, dentre elas uma que é a destacada como a que mais os impactou: assistir a um filme do Zé do Caixão. Após isso, o pesquisador injeta uma droga nos viciados e eles passam por uma experiência lisérgica, na qual são atormentados pelo Zé do Caixão. Ao final da obra, o pesquisador revela que deu um placebo aos viciados e que isso provaria 
sua tese de que as drogas não têm relação alguma com os atos nefastos praticados por eles.

Todo o filme parece se basear na tônica das discussões psicanalistas que permeavam o século XX. A análise das taras sexuais, dos comportamentos desviantes, do consumo de drogas e dos processos de violência são tratados diretamente na película. Aqui, Zé do Caixão ressurge como monstro num pesadelo lisérgico, como que confirmando as ideias de Foucault (2014) acerca da loucura através das imagens fantasiosas de Bosch. Curiosamente, os anormais não são mais seus discípulos ou ajudantes, mas sim aqueles que ele atormenta. Ao filmar a realidade, Mojica desvia da inocência do povo do interior e foca nas contradições comportamentais do cidadão urbano. Os viciados, na obra, são acusados de serem os principais perpetradores das depravações daquela sociedade. Estimulados pelas drogas, cometeriam as maiores atrocidades e representariam um risco para a sociedade como um todo. Vizeu (2005) retoma Foucault para destacar que nesse período os manicômios também serviam para abrigar viciados, homossexuais e qualquer outro tipo de pessoa que não seguisse os padrões estabelecidos para a ordem social. A consequência desse processo é a criação de uma normalização dos indivíduos (Vaz 2016), que, ao perceberem os desejos desviantes dos outros (os anormais) como algo negativo, se sentem constantemente culpados. A internalização da culpa acaba por ser um processo constante no homem moderno e isso serve como modo de manter o homem constantemente angustiado e focado em ser normal perante a ordem social. Zé do Caixão é o juiz dessa culpa e ao mesmo tempo o carrasco. Ele conduz os viciados de encontro aos seus mais internalizados temores e angústias. É por isso que aqui são os viciados quem aparece no decorrer do filme cometendo desvios sexuais. Nesse pesadelo com o inferno, eles se defrontam com todas as suas culpas internalizadas - nas cenas, eles sofrem justamente se relacionando com seus desvios morais - e são submetidos a elas.

Em 1974, inspirado pelo sucesso do ano anterior, O Exorcista (The Exorcist, 1973), de William Friedkin, Mojica lança Exorcismo Negro (1974). Num exercício de metalinguagem, Mojica interpreta a si mesmo, de férias na casa de um amigo, no interior. Logo, porém, estranhos acontecimentos e possessões começam a afetar os moradores da casa. 0 protagonista descobre então que por trás disso há uma bruxa, em conluio com o próprio Zé do Caixão, que quer interferir no destino da filha mais velha da família do amigo de Mojica. Descobre-se que essa filha é adotada pela mulher da 
família, sendo, na verdade, filha da bruxa com Zé do Caixão. A garota então está deslocada de seus laços familiares e, mesmo sem saber, é uma intrusa. As possessões são resultado de malefícios da bruxa, que quer que a garota se case com quem ela indicar e não com seu atual noivo, de quem a garota realmente gosta. Do mesmo modo, a bruxa, figura clássica do anômalo18, tenta destruir a família tradicional burguesa.

No terceiro ato, após o rapto da criança, filha mais nova da casa, criador (Mojica) e criatura (Zé) se enfrentam, num embate que marca a realidade e a ficção, mas, mais importante, o normal e o monstro. Aqui, os anormais retornam como servos do Zé do Caixão, para ajudar a aterrorizar esse ideal de família burguesa da segunda metade do século XX. Após vencer o mal usando a cruz (símbolo máximo da instituição cristã), Mojica se retira de cena, enquanto a família salva canta hinos natalinos em volta da mesa farta. A família está reunida novamente, preserva os preceitos cristãos e tradicionais e tem seus laços fortalecidos. A filha mais velha pode se casar com quem ama e nunca saberá que não é filha de sangue de sua mãe. Na última cena, porém, a menina salva observa a sombra de Zé do Caixão na parede exterior da casa. Uma amostra do mal que sempre está à espreita para entrar.

Na mesma linha, Delírios de Um Anormal retomaria essa fórmula de disputa entre criador e criatura, dessa vez de modo um pouco mais indireto, com Mojica interpretando a si mesmo para ajudar um homem que tem constantes pesadelos com Zé do Caixão. Nesses tormentos, o homem sonha que Zé rouba sua esposa, para gerar nela o filho perfeito. Apesar do nome, esse filme não explora tanto o imaginário do anormal, ainda mais que recicla em grande parte cenas de outros filmes de Mojica retidos na censura. Todavia, o anormal aqui é outro personagem apontado por Foucault (2001), o pequeno obcecado, aquele não cometeu nenhum crime, é dócil, mas carrega a loucura consigo e precisa de tratamento para suas obsessões, que podem se tornar perigosas, levando-o a se transformar também num monstro.

A Estranha Hospedaria dos Prazeres retorna à mesma forma de punição dos desviantes consolidada em O Ritual dos Sádicos. Nessa narrativa,

\footnotetext{
${ }^{18}$ Jaudy (2010) demonstra que a bruxa, além de ser a monstruosidade apontada por Douglas (2014), que trespassa as linhas sociais, é também uma demonstração do monstro disforme por verrugas, nariz alongado, face esverdeada. Além disso, ao se ligar a figura da bruxa com mulheres velhas, temos o contrário da matriarca comumente associada a uma figura bondosa e doce.
} 
Mojica interpreta um personagem praticamente igual a Zé do Caixão, com seus trejeitos e roupas. Ele recebe, em meio a uma noite de tormenta, várias pessoas em sua hospedaria, dentre eles um grupo de hippies muito parecidos com os apresentados em $O$ Ritual dos Sádicos. Ao final do filme se descobre, porém, que todos esses hóspedes morreram em algum tipo de acidente causado pela tempestade e estão reunidos ali na hospedaria, uma espécie de inferno. 0 tom punitivo da narrativa é evidente, não apenas para os anormais que estão aqui mais uma vez representados pelos hippies, mas também para todos os demais que cometeram algum tipo de delito moral, como empresários corruptos, adúlteros e suicidas.

Depois de décadas de hiato do personagem, Zé do Caixão retorna em 2008 para o último filme de sua trilogia original, Encarnação do Demônio. Dessa vez, o monstro está a solta na capital, num exercício de retorno aos personagens marginalizados da sociedade capitalista e higienista que marca o começo do século XXI. Os anormais estão em cena representados pelos servos de Zé, porém, o foco aqui parece estar muito mais nos personagens da favela, os marginalizados tanto geograficamente quanto socialmente. Nesse sentido, Encarnação do Demônio trabalha em duas vias. Primeiro, atualiza a trajetória do monstro se inserindo em um movimento de filmes que marcaram a primeira década do século XXI. Nesse movimento, se destacaram filmes retratando o cotidiano de comunidades brasileiras, popularmente conhecidas como favelas. Cidade de Deus (2002), de Fernando Meirelles e Kátia Lund, Cidade dos Homens (2007), de Paulo Morelli, e Tropa de Elite (2007), de José Padilha, são os exemplos mais famosos, sendo os dois últimos lançados apenas um ano antes de Encarnação do Demônio. Por outro lado, filmes que retratam essas comunidades não são uma completa novidade no cenário nacional: o filme de Mojica e Dennison Ramalho ${ }^{19}$ retoma suas raízes do cinema da Boca do Lixo e dos anos 1960, que lida com os marginalizados pelo sistema nas favelas. Nesse sentido, A Margem (1967), de Ozualdo Candeias, e O Assalto ao Trem Pagador (1962), de Roberto Farias, são exemplos notáveis de obras que trazem personagens muito parecidos com os explorados no filme de Mojica.

Temos assim, através dessas duas vias, o retrato da higienização promovida pelas forças coercitivas dos agentes do Estado daqueles à

${ }^{19}$ Roteirista e co-diretor de Encarnação do Demônio. 
margem. Antes de executar algumas crianças na favela, um dos policiais sentencia: "Lição número um: segurança para a população, economia para o Estado". A fala sintetiza todo um pensamento denunciado por Foucault (2012) desde a segunda metade do século XX. Cada vez mais, a preocupação é em punir não apenas pelo ato em si, mas sim pelo potencial desvio de caráter, pelo possível perigo que determinado ser representa à sociedade. São cenas que se repetem desde $O$ Assalto ao Trem Pagador, quando os investigadores e jornalistas reviram a casa da esposa de Tião, em busca do dinheiro roubado até as subidas do Batalhão de Operações Policiais Especiais (BOPE) nos morros do Rio de Janeiro, representadas em Tropa de Elite. Em todos esses casos, se apresenta a supressão dos marginalizados, a execução das anomalias e constante separação dos desajustados. Tal ponto, se relaciona provavelmente com a entrada de outro roteirista na obra de Mojica. Trata-se de Dennison Ramalho, cineasta que sempre priorizou a crítica social em seus trabalhos. Dennison se insere, de igual modo, numa nova safra de cineastas brasileiros que trabalham o cinema de horror e sua relação com o cotidiano social.

O personagem monstruoso de Zé do Caixão segue muito próximo aos dois primeiros filmes da trilogia, amaldiçoa as crenças dos moradores locais, briga com representantes do Estado e tortura policiais. Do mesmo modo, ele é o monarca estrangeiro, se porta de modo diferente e distante dos moradores. Aqui, por outro lado, ele se mostra como um protetor deles, afinal o grande monstro se mostra na figura das instituições, dos milicianos que promovem a higienização social da comunidade. Portanto, ao mesmo tempo em que mantém suas raízes clássicas, Zé é atualizado, a fim de lidar com os problemas atuais daquela sociedade. Tal influência também pode apontar ao status que o personagem adquiriu com o tempo, passando de vilão a certa figura heroica para a população marginalizada.

O final de Encarnação do Demônio segue o mesmo preceito dos dois primeiros filmes, com a morte de Zé. Aqui, ele é executado pelo padre Eugênio (Milhem Cortaz), que ainda excomunga sua alma, o condenando ao inferno pelos pecados. Retomemos aqui, por fim, os apontamentos de Foucault acerca do monstro e sua perspectiva jurídica. Como comentamos no começo deste artigo, é no século XVIII que se estabelece noção do monstro como a parte das leis, como aquele quem quebra o contrato social e, portanto, não pode ser por ele julgado. Logo, sua sentença é a exclusão. Se nos dois primeiros filmes já temos a exclusão do corpo de Zé, através de suas mortes, no ato final da trilogia, temos, além disso, a exclusão de sua alma.

anikiEnsaios | Essays 


\section{Considerações Finais}

Ao retraçar a filmografia de horror de José Mojica Marins fica evidente a importância do personagem do monstro e dos anormais. Advindo da região da Boca do Lixo ${ }^{20}$, lugar à margem social da cidade de São Paulo, o diretor soube bem trabalhar com a fama de desajustado e louco que lhe impuseram tanto como elogio quanto como depreciação. Mojica buscou atrair curiosos e fãs com essas críticas.

Em seus filmes, todavia, é percebido o uso dos anormais a partir de diferentes visões. Primeiramente, eles são os servos de Zé do Caixão, aqueles indisciplinados que não têm salvação nem senso moral e que ajudam o grande monstro a infligir tormentos aos normais. Excetuando-se Exorcismo Negro, que segue essa toada, os filmes a partir de $O$ Ritual dos Sádicos apresentam um deslocamento da figura do anormal. Agora ele é o desviante moral mais próximo de nossa realidade. Não é mais um ser fantástico e disforme no corpo, mas sim o errante moral. Ele se torna vítima do monstro e é punido por ser o responsável por subverter a ordem moral da sociedade. Já em Encarnação do Demônio, obra inserida em outro século e com uma diferente equipe, os anormais estão presentes como ajudantes de Zé, não obstante, o foco está nos marginalizados pelo Estado. 0 monstro maior aqui se dilui nos personagens dos policiais, que cometem todo tipo de crimes. Zé continua encarnando o mal, porém, acaba por proteger a comunidade de um monstro maior.

Do mesmo modo, concluímos que Zé do Caixão se constitui através de duas concepções de monstro. Primeiro, a do horror, remetendo para os personagens das narrativas góticas e da Universal Studios: a roupa e o modo de se portar de Zé do Caixão remetem para o Conde Drácula, enquanto que alguns dos seus súditos anormais remetem para outros personagens, como os ajudantes do Dr. Frankenstein. Porém, mais importante para o nosso artigo é perceber que Zé se configura também a partir do monstro jurídico, isto é, a figura monstruosa que se coloca à parte das leis, que transforma seus atos em ethos. Se na trilogia original, Zé é mais próximo do humano, nas demais obras, ele se torna como que uma entidade, se aproximando mais do monstro do horror artístico de Carroll, ou seja, aquele que abala o mundo das vítimas, abre as normas ${ }^{20}$ Atualmente, a Boca é um bairro conhecido por ser local de prostituição e reduto de moradores de rua e
dependentes químicos, talvez as figuras de anormais mais comuns no imaginário popular. 
culturais e as critica. Todavia, no fim, é sempre vencido, reestabelecendo e fortificando a norma. Do mesmo modo, é possível perceber a mudança no percurso de Zé do Caixão em seus filmes. Seja como monstro monárquico, seja como revolucionário sanguinolento, Zé é marcado por estar sempre deslocado de seu meio social e antropológico. Não à toa seu valor de peste e desordem sempre vem à tona com suas características criminosas. Além disso, Zé carrega os preceitos do monstro estabelecido juridicamente no século XVIII, aquele que quebra o contrato social e da sociedade deve ser apartado.

Esse percurso mostra os constantes deslocamentos da visão de Mojica e seus roteiristas, Rubens Luchetti e Dennison Ramalho, nas concepções de anormais e monstros. Nesse sentido, tanto Luchetti quanto Ramalho evidenciam um diálogo com suas respectivas épocas na construção de seus textos e personagens. Este último, inclusive, traz consigo discussões atuais, que revigoram a filmografia de Mojica. As mudanças nessas tramas envolvem tanto a participação de diferentes pontos de vista na contribuição do trabalho de Mojica, quanto com novos processos históricos, culturais, sociais e até mercadológicos. Enquanto que nos primeiros filmes temos monstros e anormais que se relacionam com o cinema de horror clássico, em Exorcismo Negro observamos uma relação que advém justamente desse novo subgênero do horror, o filme de possessão. Do mesmo modo, Encarnação do Demônio tem um novo deslocamento, dialogando com obras do mesmo período que se preocupam em mostrar o cotidiano violento das comunidades periféricas brasileiras. Não por acaso os olhares dos envolvidos nessas tramas mudam, seguindo as rápidas alterações do breve e turbulento século XX. Além disso, 44 anos, diversos movimentos cinematográficos e acontecimentos históricos e sociais separam À Meia Noite Levarei Sua Alma de Encarnação do Demônio.

Por fim, salientamos que este artigo não deve encerrar esta temática por aqui, restando questões em aberto. A principal delas é salientar que outros aspectos religiosos muito presentes na filmografia de José Mojica Marins podem render ricas análises, sendo o exemplo mais notável as relações entre as tramas e as religiões de matriz africana. Tal ponto não foi abordado aqui por motivos de foco e espaço, merecendo um estudo à parte. Além disso, é possível questionar como os anormais e os monstros são apresentados em outras obras do horror nacional, principalmente nos filmes lançados na última década, que revigoraram o gênero, até então muito preso a figura de Zé do Caixão. 


\section{Referências}

Bakhtin, Mikail. 1987. A Cultura Popular na Idade Média e no Renascimento: $O$ contexto de François Rabelais. São Paulo: Hucitec.

Barcinski, André e Ivan Finotti. 2015. Zé do Caixão: Maldito - a biografia. Rio de Janeiro: Darkside Books.

Carroll, Nöel. 1999. A Filosofia do Horror ou Paradoxo do Coração. Campinas: Papirus Editora.

Clark, Stuart. 2006. Pensando com Demônios: A idéia de bruxaria no princípio da Europa Moderna. São Paulo: Editora da Universidade de São Paulo.

Cohen, Jeffrey. 2000. Pedagogia dos Monstros: Os prazeres e os perigos da confusão de fronteiras. Belo Horizonte: Autêntica.

Douglas, Mary. 2014. Pureza e Perigo. São Paulo: Perspectiva.

Foucault, Michel. 2014. História da Loucura: Na Idade Clássica. São Paulo: Perspectiva.

. 2001. Os Anormais: Curso no Collège de France (1974-1975). São Paulo: Martins Fontes.

. 2012. "Atenção: Perigo." In Ditos e Escritos VIII: Segurança, penalidade e prisão, organizado por Manoel Barros da Motta, 113114. Rio de Janeiro: Forense Universitária.

Gil, José. 2006. Monstros. Lisboa: Relógio d'Água.

Jaudy, Faud J.R. 2010. Faces da Monstruosidade. Dissertação de Mestrado. Cuiabá, Programa de Pós-Graduação em Estudos da Cultura Contemporânea - Universidade Federal de Mato Grosso.

Lemos, Fabiano. 2014. "Kant e o Monstro." Kriterion, 129: 189-203. https://doi.org/10.1590/S0100-512X2014000100011

Melo, Marcelo B.M. 2010. Zé do Caixão: Personagem de horror. Tese de Doutorado. São Paulo, Programa de Pós-Graduação em Comunicação Social - Universidade Metodista de São Paulo.

Portocarrero, Vera. 2014. "Instituição Escolar e Normalização em Foucault e Canguilhem.” Educação e Realidade, 29 (1): 169-185. https://seer.ufrgs.br/educacaoerealidade/article/view/25424

Ricoeur, Paul. 1982. Finitud y Culpabilidad. Madrid: Taurus Ediciones.

Santos, Matheus A. 2013. Imagem-abjeto: Um estudo sobre manifestações estéticas da abjeção. Dissertação de Mestrado. Rio de Janeiro, 
Programa de Pós-Graduação em Comunicação e Cultura - Escola de Comunicação da Universidade Federal do Rio de Janeiro.

Schiller, Friedrich. 2011. Do Sublime ao Trágico. Belo Horizonte: Autêntica Editora.

Tucherman, Ieda. 2012. Breve História do Corpo e de seus Monstros. Lisboa: Nova Vega.

Vaz, Paulo. 2016. “O processo de normalização." In Michel Foucault e os Saberes do Homem: Como, na orla do mar, um rosto na areia, organizado por Heliana Rodrigues, Vera Portocarrero e Alfredo Veiga-Neto, 485-504. Curitiba: Editora Prismas.

Vigarello, Georges. 1996. O Limpo e o Sujo: Uma história da higiene corporal. São Paulo: Martins Fontes.

Vizeu, Fábio. 2005. “A Instituição Psiquiátrica Moderna sob a Perspectiva Organizacional.” História, Ciências, Saúde - Manguinhos, 12 (1): 3349. https://doi.org/10.1590/S0104-59702005000100003

\section{Filmografia}

A Estranha Hospedaria dos Prazeres. Dir. José Mojica Marins. Produções Cinematográficas Zé do Caixão, Brasil, 1976, 81 mins.

A Margem. Dir. Ozualdo Candeias. Ozualdo R. Candeias Produções Cinematográficas, Brasil, 1967, 96 mins.

À Meia-Noite Levarei sua Alma. Dir. José Mojica Marins. Indústria Cinematográfica Apolo, Brasil, 1964, 84 mins.

Bird Box. Dir. Susanne Bier. Netflix et. al., Estados Unidos, 2018, 124 mins.

Cidade de Deus. Dir. Fernando Meirelles, Kátia Lund. 02 Filmes et. al., Brasil, 2002, 135 mins.

Cidade dos Homens. Dir. Paulo Morelli. 02 Filmes et. al., Brasil, 2007, 110 mins.

Delírios de um Anormal. Dir. José Mojica Marins. Produções Cinematográficas Zé do Caixão, Brasil, 1978, 86 mins.

Encarnação do Demônio. Dir. José Mojica Marins. Olhos de Cão, Gullane Filmes, Brasil, 2008, 90 mins.

Esta Noite Encarnarei no teu Cadáver. Dir. José Mojica Marins. Ibéria Filmes, Brasil, 1967, 108 mins. 
Exorcismo Negro. Dir. José Mojica Marins. Cinedistri, Brasil, 1974, 100 mins.

In the Mouth of Madness. Dir. John Carpenter. New Line Cinema, Estados Unidos, 1994. 95 mins.

O Assalto ao Trem Pagador. Dir. Roberto Farias. Produções Cinematográficas Herbert Richers, Brasil, 1962, 102 mins.

O Estranho Mundo de Zé do Caixão. Dir. José Mojica Marins. Ibéria Filmes, Brasil, 1968, 80 mins.

O Ritual dos Sádicos. Dir. José Mojica Marins. Multifilmes, Brasil, 1970, 93 mins.

Tropa de Elite. Dir. José Padilha. Zazen Produções Audiovisuais, Brasil, 2007, 118 mins.

Vargtimmen. Dir. Ingmar Bergman. Svensk Filmindustri, Suécia, 1968, 84 mins.

\title{
The Monster and the Abnormal in José Mojica Marins' Filmography
}

\begin{abstract}
This article examines the character of Coffin Joe, created by José Mojica Marins, using as a starting point the concept of "monster" and articulating concepts created by Mary Douglas, Noël Carroll and Michel Foucault. Likewise, the text investigates the various structural features of some of the characters in the director's filmography that match the concept of "abnormal", coined by Michel Foucault. In order to do so, the article draws on these authors' writings and undertakes a close reading of José Mojica Marins' movies, assessing how those characters are established in different moments. Our conclusions refer to the relationship between these films and their social contexts, as they are inserted in multiple chronological epochs, emphasizing the importance of analyzing monsters and the abnormal through this set of theoretical frameworks.
\end{abstract}

KEYW ORDS José Mojica Marins; Coffin Joe; Monster; Abnormal

Recebido a 6-8-2020. Aceite para publicação a 23-10-2020.

anikiEnsaios | Essays 